\title{
Екстракорпорална септопластика
}

\author{
Extracorporeal Septoplasty
}

\author{
Пл. Недев*, К. Керимов*, М. Милков** \\ "Клиника по УНГ-болести при УМБАЛ „Св. Марина” - Варна \\ **Медицински университет - Варна, Факултет по дентална медицина
}

\begin{abstract}
Резюме
При реконструкция на тежки септални деформитети за възстановяване на носното дишане се предпочита отстраняването на хрущяла на носната преграда, моделирането му извън носната кухина и връщането му обратно. Екстракорпоралната септопластика представлява радикално решение за „трудните” изкривявания на носната преграда. Целта на настоящата статия е да представи нашия опит при 73 случая с тази техника посредством отворен достьп при 50 пациенти и при 23 чрез ендоназален достьп.
\end{abstract}

Ключови думи: екстракорпорална септопластика, отворен достъп, септопластика.

\begin{abstract}
To reconstruct the airways in the case of serious nasoseptal deviation it is preferable to remove the cartilaginous septum, reshape it, , and replacement of the quadrangular cartilage (put it back). Extracorporeal septoplasty is a radical solution for the "difficult" (severely) deviated nosal septum. The aim of this paper is to present our experience of 73 cases of correction of nasoseptal deviation of 50 patients with open approach, and 23 patients by endonasal approach.
\end{abstract}

Keywords: Extracorporeal septoplasty, open approach, septoplasty.

\section{Увод}

Септопластиката е оперативна интервенция, целяща медианизиране на носната преграда и възстановяване на нарушените ринологични функции. Септумът, в зависимост от деформитета, би могъл да се изправи, изгради или замести (Massing 1977). Често девиираната носна преграда оказва влияние и върху формата на носа и неговата естетична функция. Обикновено в тези случаи са касае за тежки деформитети, водещи до изкривяване на външния нос. Използването на обичайните септопластични процедури тук не води до желаната корекция, което компрометира както статичната, така и динамичната роля на носната преграда. Екстракорпоралната септопластика е алтернативна техника, която позволява пълна и надеждна реконструкция на носната преграда.

\section{Материал и методи}

За периода 2000 - 2008 г. оперирахме 73 пациенти (45 мъже и 28 жени), при които се изпълни екстракорпорална септопластика. Според нашата класификация (Недев 2002, 2008) септалните деформитети се разделят на прости (кранио-каудални или дорзо-вентрални), смесени и сложни. В зависимост от отстоянието към латералната носна стена се определя I или II степен. При нашите пациенти 60 бяха със сложни, а 13 със смесени деформитети от II степен.

След обща интубационна анестезия прилагаме инфилтрация на локален анестетик с цел хидравлична дисекция и ограничаване на интраоперативното кървене. При 50 пациенти се приложи външен, а при 23 - ендоназален достьп. Носната преграда се отпрепарира двустранно. Хрущялната част се отделя от 
костната основа, Vomer, Lamina perpendicularis и триангуларните хрущяли. След това носната преграда се моделира екстракорпорално под формата на буквата „L“ или се пришиват отделни фрагменти с нерезорбируем конец 5 00. Оформената хрущялна част се реимплантира обратно, като новоизградената носна преграда се фиксира за триангуларните хрущяли, spina nasalis anterior и ако се наложи, за медиалните крачета на аларните хрущяли. Провеждат се и задължителни трансмукоприближаващи сутури с резорбируем конец 3 00. Пришиват се и придържащи сплинтове. В края на операцията се зашива достьпьт и се поставя рехава тампонада. Тя се отстранява на следващия ден, а сплинтовете - между 7 и 10 дни. При ринопластика се поставя и външна фиксираща превръзка, която премахваме на седмия ден.

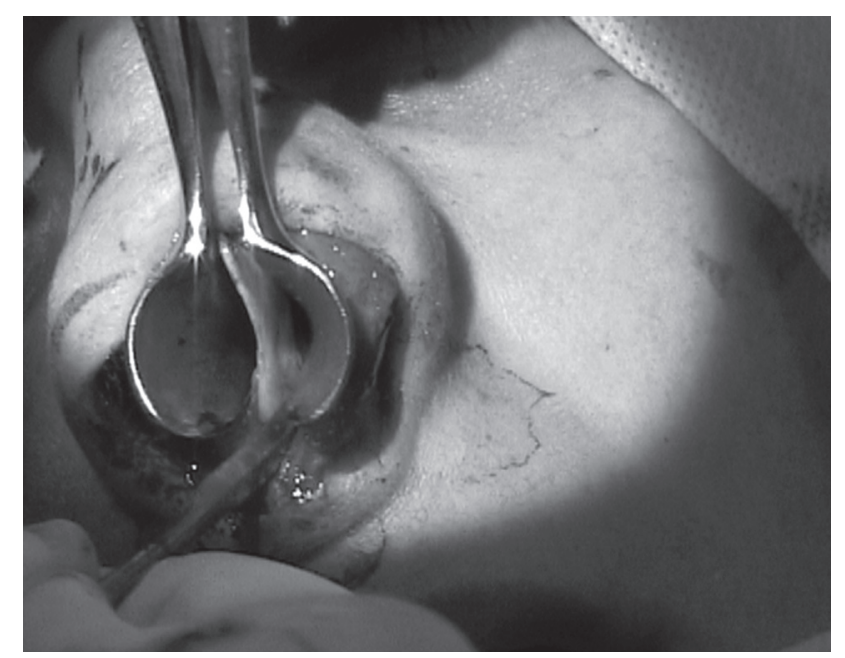

Фиг. 1. Експониране на носната преграда след отделяне на медиалните крачета при външен достъп

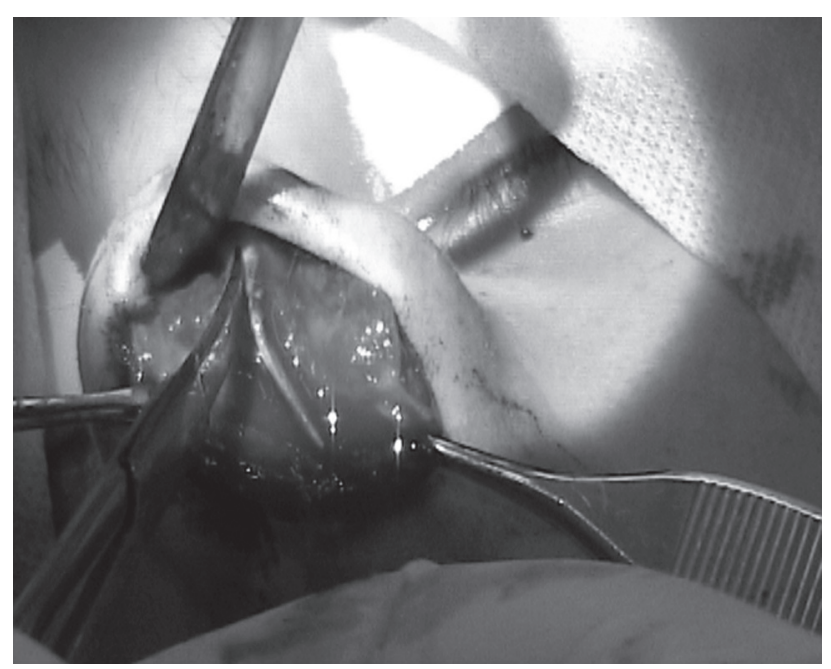

Фиг. 2. Отделяне на септума от триангуларните хрущяли

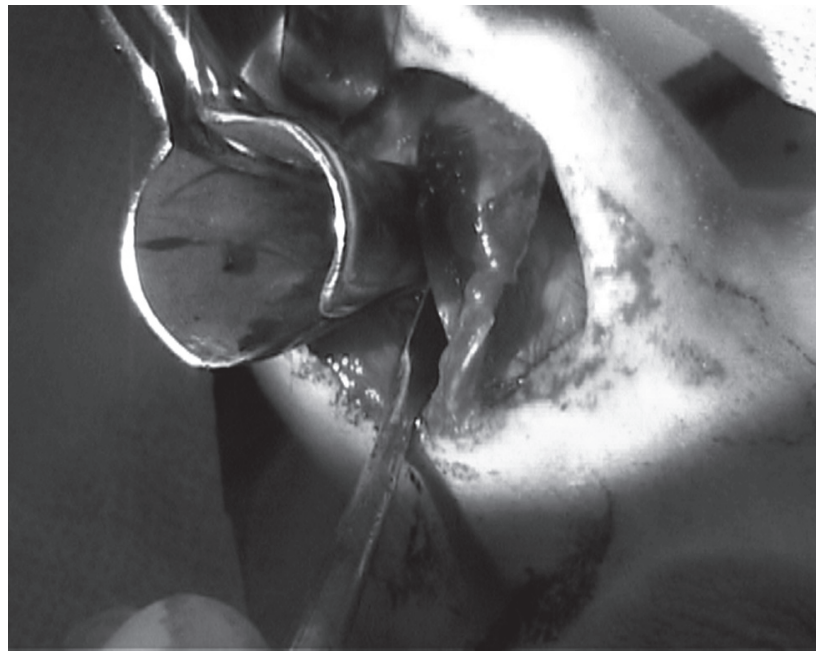

Фиг. 3. Отделяне на хрущяла на носната преграда от Lamina perpendicularis

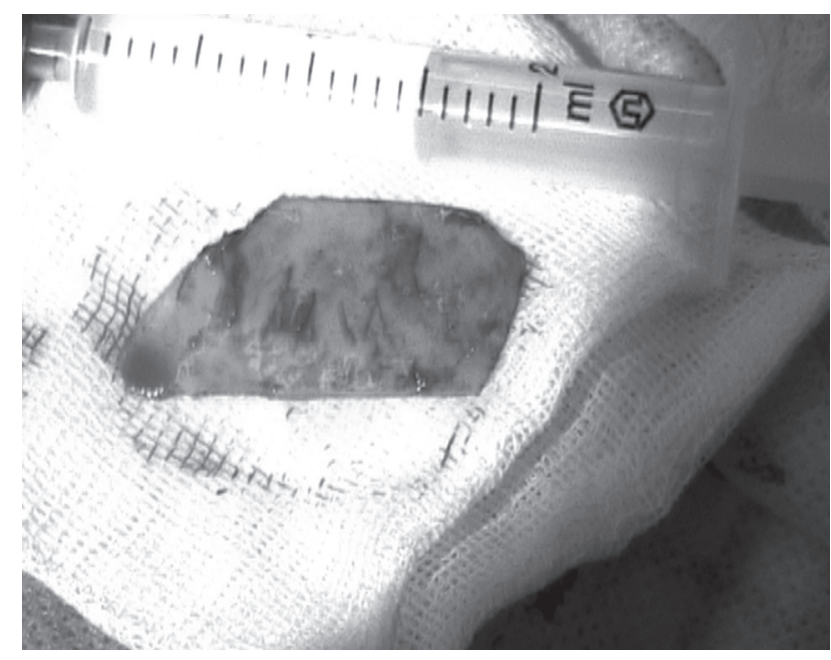

Фиг. 4. Cartilago cuadrangularis

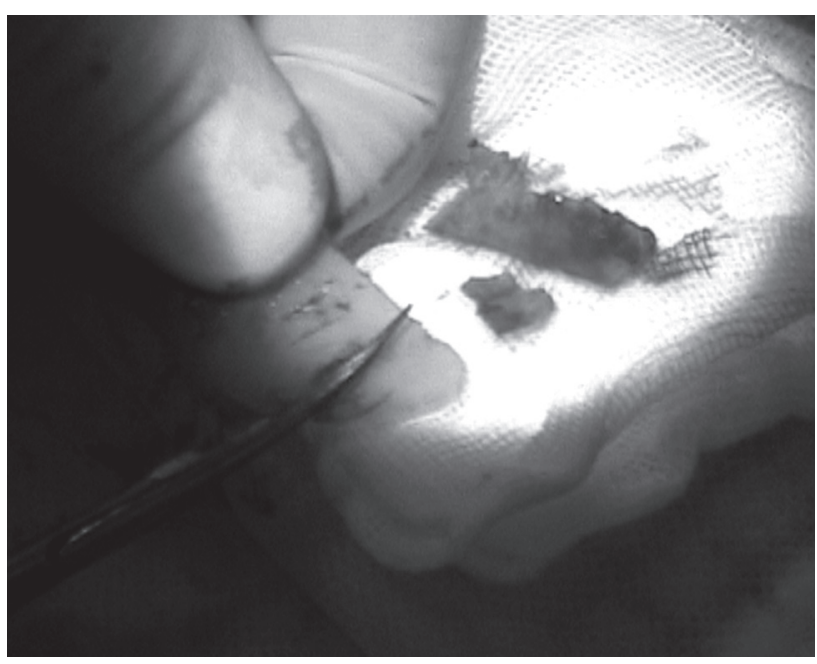

Фиг. 5. Екстракорпорално моделиране на носния септум 


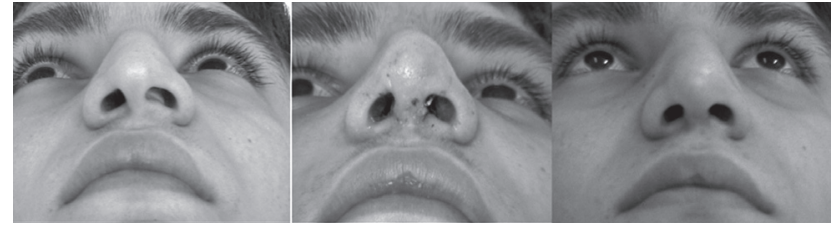

Фиг. 6. Пациент преди операцията (вляво), седем дни след това (в средата) и една година след операцията (вдясно)
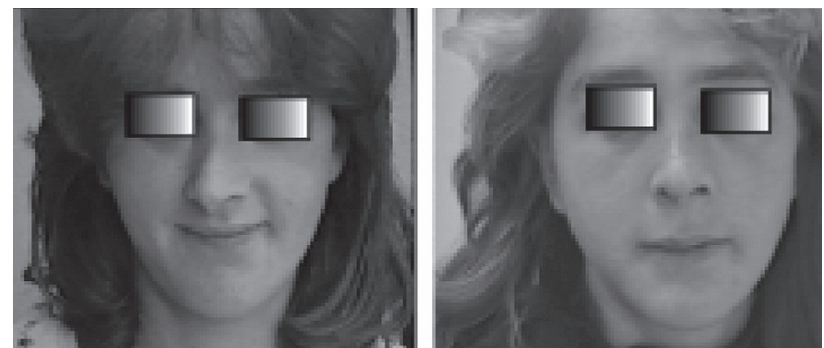

Фиг. 7. Пациентка с хрущялно крив външен нос (вляво преди операцията). Една година след операцията (вдясно)

\section{Резултати и обсьждане}

За първи път в литературата екстракорпоралната септопластика е описана от Kings и Ashley през 1952 г. и Penet през 1958 г., след което е доразвита и утвърдена от Massing през 1977 г. (Gubisch 2008). В достьпната ни литература открихме, че Gubisch (2005) е извършил 2119 екстракорпорални септопластики, като усложненията са били едва $4 \%$ с резидуална девиация, $8 \%$ седловиден нос.

При нашите пациенти установихме резидуална девиация при трима (4\%), при един $(0,7 \%)$ - хематом на носната преграда, и резидуален седловиден нос при 10 (7,3\%), резидуален външен деформитет на носа - при четирима $(5,4 \%)$. Тези компликации са съизмерими с данните на повечето автори - Rees (1995), Gubisch (2005)

Въз основа на нашия опит при повече от 1000 септопластики за периода 1986 - 2009 г. ние стигнахме до извода, че, особено при смесени и сложни деформитети от II степен класическите септопластични процедури, като тези, предложени от Cottle (1959),

\section{Литература:}

1. Gubisch W.; Das schwierige Septum. HNO; 1988, 36: 286-289

2. Guisch W.; Zum Problem der Spaltnasenkorrektur bei einseitigen Spaltbildungen HNO; 1989, 37: 415-422

3. Gubisch W. The extracorporeal septum plasty: a technique to correct dif. culty nasal deformities. Plast Reconstr Surg 1995; 95: 672-682

4. Gubisch W; Extracorporeal Septoplasty for the Markedly Deviated Septum Arch Facial Plast Surg. 2005;7:218-226. не водят до желан или очакван резултат. Екстракорпоралната септопластика дава възможност да се извърши пълна реконструкция на „трудните” септуми. За нейното прецизно изпълнение външният достъп е предпочитан пред ендоназалния. Той осигурява много по-добра видимост и позволява прецизното фиксиране на новата носна преграда. В същото време от особена важност е фиксирането към триангуларните хрущяли, което осигурява поддръжка на носната преграда от горната страна и оформянето на гърба на носа. Фиксирането към предна назална спина осигурява поддръжката отпред и от долната страна, а трансмукосепталните сутури осигуряват прибирането на мукоперихондриалните ламба и също спомагат за стабилността на септума. При недобро или нежелано извършване на сутурите е възможно премахването им и извършване на ново фиксиране. Външният достъп позволява тази маневра да се изпълни прецизно и надеждно.

\section{Заключение и изводи}

1. Екстракорпоралната септопластика е радикална оперативна интервенция, целяща пълна реконструкция на носната преграда.

2. Външният достъп е препоръчителен за изпълнението на тази техника.

3. Екстракорпоралната септопластика е трудна за изпълнение оперативна интервенция, изискваща по-дьлго интраоперативно време и подълъг следоперативен период.

4. Коректната екстракорпорална септопластика изисква след моделиране и реимплантиране на носната преграда да се осъществи фиксирането ѝ към латералните и при необходимост към медиалните крачета на аларните хрущяли, предна носна спина и да се приложат трансмукосептални сутури.

5. Екстракорпоралната септопластика следва да се извършва при т. нар. „трудни“ септуми и деформитети на външния нос, обусловени от девиирана носна преграда.

5. Rees TD: Removal of the septum and its replacement as a graft for the difficult nasal deformity. Plast Reconstr Surg. 1995, 96: 1486, (letter)

6. Недев Пл. Хирургично лечение на затрудненото носно дишане дължащо се на изкривена носна преграда. Дисертация. София 2002

7. Nedev P1. A three dimensional classification of nasal septum deformities. Hellenic Otorhinolaryngology - Head and Neck Surgery 2008 